\title{
Model Problem Based Learning Untuk Meningkatkan Kemampuan Berpikir Kritis dan Hasil Belajar IPA Siswa
}

\author{
Janista Windi Mareti ${ }^{1}$, Agnes Herlina Dwi Hadiyanti ${ }^{*}$ \\ 1Universitas Sanata Dharma, Yogyakarta, Indonesia \\ 2Universitas Sanata Dharma, Yogyakarta, Indonesia \\ *Corresponding Author: agnes.hadiyanti@usd.ac.id
}

\begin{abstract}
This classroom action research aims to improve critical thinking skills and learning outcomes of fifth-grade students in science subjects through the application of the Problem Based Learning (PBL) learning model. The subjects of this study are fifth-grade students in SD Kanisius Sengkan. This research used observation, interviews, and tests to collect the data. The results of this study indicate that (1) the Problem Based Learning $(P B L)$ model can improve students' critical thinking skills after each cycle. This can be seen by the rise in the students' mean scores in critical thinking skills results: 64,1818 in the first cycle and 80,38 in the second cycle; (2) the Problem Based Learning (PBL) learning model can improve students' achievement. This can be seen by the rise in the students' mean scores in the test results: 69,3 in the first cycle and 76,21 in the second cycle.
\end{abstract}

Keywords: critical thinking; learning outcome; problem based learning (PBL)

\section{ABSTRAK}

Penelitian ini dilatarbelakangi oleh rendahnya kemampuan berpikir kritis dan hasil belajar siswa terhadap pembelajaran IPA di SD Kanisius Sengkan. Penelitian ini bertujuan untuk: meningkatkan kemampuan berpikir kritis dan hasil belajar siswa kelas $\mathrm{V}$ pada mata pelajaran IPA melalui penerapan model pembelajaran Problem Based Learning (PBL). Jenis penelitian ini adalah penelitian tindakan kelas. Subjek dari penelitian ini adalah siswa kelas VA SD Kanisius Sengkan. Objek penelitian yaitu peningkatan sikap berpikir kritis dan hasil belajar IPA siswa menggunakan model pembelajaran Problem Based Learning (PBL). Penelitian ini menggunakan teknik pengumpulan data berupa observasi, wawancara dan tes. Hasil dari penelitian ini menunjukkan bahwa (1) model pembelajaran Problem Based Learning (PBL) dapat meningkatkan kemampuan berpikir kritis siswa, ditunjukkan dengan skor rata-rata kemampuan berpikir kritis pada siklus I yaitu 64,18 menjadi 80,38 pada siklus II. (2) model pembelajaran Problem Based Learning (PBL) dapat meningkatkan hasil belajar siswa dari nilai kondisi awal rata-rata 69,3 meningkat menjadi 76,21 pada siklus I dan meningkat kembali pada siklus II yaitu 82,19.

Kata Kunci: berpikir kritis; hasil belajar; problem based learning (PBL)

\section{Pendahuluan}

Belajar merupakan suatu aktivitas mental atau psikis yang berlangsung dalam interaksi aktif dengan lingkungan demi menghasilkan perubahan-perubahan dalam pengetahuan, keterampilan, dan nilai sikap (Winkel dalam Purwanto, 2013). Pembelajaran abad 21 menuntut manusia memiliki kemampuan berpikir dengan baik dalam membuat keputusan serta menyaring informasi. Dengan demikian, berpikir kritis merupakan suatu kecakapan yang sangat diperlukan dalam proses pembelajaran dan penting untuk dikembangkan sejak dini terutama pada pendidikan tingkat sekolah dasar.

Salah satu keterampilan belajar abad 21 yang perlu dikuasai siswa adalah memiliki kemampuan berpikir kritis. Berpikir kritis merupakan suatu kecakapan yang menjadi modal intelektual bagi siswa sebagai bagian yang terpenting dari kematangan berpikir. Setiap orang harus mencari tahu apa hal yang bisa dipercayai dan melaksanakannya dengan langkah yang sesuai. Tujuan diajarkan berpikir kritis adalah agar siswa dapat belajar cara mengatasi masalah 
secara terstruktur dan kreatif, sehingga dapat menemukan berbagai alternatif solusi. Kemampuan berpikir kritis ini dapat dikembangkan dalam proses pembelajaran di sekolah. Pembelajaran dapat dikatakan baik apabila pembelajaran yang dilaksanakan bukan hanya menyampaikan materi yang harus dikuasai siswa, namun pembelajaran tersebut harus bisa merangsang kemampuan siswa untuk belajar secara mandiri (Riyana, 2012). Facione (2013) menegaskan bahwa berpikir kritis merupakan penentuan keputusan terhadap apa yang harus dilakukan dan diyakini melalui sebuah jalan refleksi. Berpikir kritis merupakan suatu sikap mau berpikir secara mendalam tentang masalah-masalah dan hal-hal yang berada dalam jangkauan pengalaman seseorang (Fisher, 2009). Norris (dalam Sani, 2019) mengatakan, seorang pemikir kritis akan berupaya mencari alasan pemikiran, informasi yang cukup, menggunakan sumber yang dapat dipercaya dan menyatakan sumber tersebut, mencari alternatif, mempertimbangkan pandangan orang lain dan diri sendiri secara serius, menahan pertimbangan jika bukti dan alasan tidak cukup kuat, mencari sebanyak mungkin informasi yang akurat.

Proses pembelajaran di kelas pada umumnya hanya diarahkan pada kemampuan menghafal informasi. Siswa hanya dipaksa untuk mengingat dan menimbun berbagai informasi tanpa dituntut untuk memahami informasi yang diperoleh untuk menggabungkannya dengan situasi dalam kehidupan sehari-hari. Pembelajaran dengan menekankan pada hafalan tidak akan mampu mengembangkan kemandirian belajar dan juga tidak dapat mengoptimalkan kemampuan berpikir kritis pada siswa. Rendahnya kemampuan berpikir kritis siswa yang berdampak pada hasil belajar siswa merupakan permasalahan yang sering muncul dalam pembelajaran IPA. Kemampuan berpikir kritis siswa sangat penting dalam proses pembelajaran, bukan hanya menghafalkan materi yang belum tentu mereka pahami. Kemampuan berpikir kritis dapat mempengaruhi hasil belajar siswa, jika kemampuan berpikir siswa rendah maka akan berdampak pula pada hasil belajarnya. Hal ini diperkuat oleh Prihanti (2015) yang mengemukakan bahwa kemampuan berpikir kritis dalam proses pembelajaran dapat membuat retensi belajar lebih tinggi, pembelajar lebih aktif, pengetahuan yang didapat lebih luas, mampu memilah informasi atau sumber belajar yang tepat. Maka guru harus memilih strategi pembelajaran yang dapat meningkatkan kemampuan berpikir siswa. Dalam mata pelajaran IPA seharusnya guru memberikan pengalaman langsung supaya siswa benar-benar paham. Selain itu siswa juga dapat belajar dari permasalahan yang terjadi di sekitar dan mencoba memecahkan masalah tersebut.

Kemampuan berpikir kritis sangat penting terutama dalam pembelajaran, karena merupakan salah satu sikap ilmiah yang harus dimiliki siswa ketika pembelajaran IPA. Jika siswa kurang memiliki kemampuan berpikir kritis maka siswa akan kesulitan untuk memecahkan persoalan atau permasalahan pada pembelajaran IPA. Hal ini dapat mempersulit siswa untuk memahami konsep pembelajaran IPA, yang akan mempengaruhi pengetahuan siswa yang tidak berkembang dan akan berdampak pada rendahnya hasil belajar siswa. Siswa yang kurang memiliki kemampuan berpikir kritis ini cenderung kurang aktif ketika pembelajaran berlangsung. Siswa tersebut hanya menerima dari guru tanpa menyaring informasi yang ia terima tanpa mengungkapkan pendapat yang ada dalam pikirannya. Hal tersebut yang membuat siswa kurang memahami materi yang diajarkan. Selanjutnya ketika guru memberikan soal evaluasi siswa yang bertujuan untuk mengukur pemahaman materi siswa akan mendapat nilai yang kurang memuaskan, sehingga berpengaruh pada rendahnya 
hasil belajar siswa. Oleh karena itu, kemampuan berpikir kritis siswa penting untuk distimulus dan ditingkatkan dalam proses pembelajaran agar akhirnya berdampak juga pada peningkatan hasil belajarnya.

Berdasarkan hasil observasi yang dilakukan di SD Kanisius Sengkan diketahui bahwa kemampuan berpikir kritis siswa masih tergolong sangat rendah. Hal ini ditunjukkan dari data hasil observasi terkait kemampuan berpikir kritis yang hanya mencapai skor 37.07. Hal itu menunjukkan bahwa hampir 70\% siswa masih memiliki sikap berpikir kritis yang rendah. Dari hasil observasi tersebut terlihat banyak siswa yang masih diam dan pasif saat menerima materi yang diajarkan. Siswa masih banyak yang melamun dan tidak tertarik untuk belajar. Untuk pengambilan data observasi, ada 6 indikator yang digunakan yaitu 1) bertanya dan menjawab pertanyaan sesuai dengan permasalahan yang dibahas, 2) menarik kesimpulan dari permasalahan yang dibahas, 3) mengumpulkan dan menyusun informasi dari permasalahan yang dibahas, 4) menemukan dan merumuskan masalah yang berkaitan dengan materi yang disampaikan, 5) menemukan strategi/cara untuk menyelesaikan permasalahan yang dibahas, dan 6) menganalisis argumen. Dari enam indikator yang menjadi pedoman dalam melakukan observasi tersebut, hanya ada 2 indikator yang terlihat pada siswa, salah satunya adalah menjawab pertanyaan guru. Permasalahan terkait kurangnya kemampuan berpikir kritis siswa ini kemungkinan terjadi karena penerapan model pembelajaran yang masih konvesional.

Selain observasi, peneliti juga melakukan pengambilan data nilai siswa pada muatan pelajaran IPA. Berdasarkan data tersebut, diketahui bahwa hanya kurang dari 50\% siswa yang dapat berhasil mencapai kriteria ketuntasan minimal (KKM) yang ditetapkan yaitu 68. Dari siswa kelas VA yang berjumlah 22 siswa dengan nilai rata-rata kelas yaitu 69.3, siswa yang mencapai KKM hanya sebanyak 9 siswa atau sebesar $40.90 \%$, sedangkan siswa yang mendapatkan nilai di bawah KKM sebanyak 13 siswa atau sebesar 59.10\%. Data observasi tersebut diperkuat dengan data wawancara yang diperoleh dari Guru kelas VA SD Kanisius Sengkan. Wawancara membahas tentang permasalahan-permasalahan yang ada selama proses pembelajaran di kelas. Berdasarkan hasil wawancara diketahui bahwa siswa masih mengalami kesulitan dalam mata pelajaran IPA. Materi yang disampaikan sangat sulit dipahami siswa. Khususnya pada materi sistem pernapasan pada manusia. Dari hasil wawancara ini juga diperoleh data bahwa siswa masih sangat pasif dan tidak memiliki rasa penasaran terhadap materi yang disampaikan. Kemampuan berpikir kritis siswa yang tidak tampak dalam dirinya membuat siswa malu untuk bertanya dan kurang aktif untuk mengeksplorasi pengetahuan-pengetahuan yang dimiliki sehingga berdampak pula pada hasil belajarnya. Oleh karena itu, dibutuhkan suatu strategi dengan penerapan model pembelajaran yang inovatif agar kemampuan berpikir kritis dan hasil belajar siswa dapat meningkat. Salah satu model pembelajaran yang diyakini dapat meningkatkan kemampuan berpikir kritis dan hasil belajar siswa adalah model Problem Based Learning.

Joy \& Weil (dalam Rusman, 2012) mengatakan bahwa model pembelajaran adalah suatu rencana atau pola yang dapat digunakan untuk membentuk kurikulum (rencana pembelajaran jangka panjang), merancang bahan-bahan pembelajaran, dan membimbing pembelajaran di kelas atau yang lain. Soekamto (dalam Suprijono, 2016) menjelaskan bahwa model pembelajaran adalah kerangka konseptual yang melukiskan prosedur sistematis mengorganisasikan pengalaman belajar untuk mencapai tujuan belajar tertentu dan berfungsi 
sebagai pedoman bagi para perancang pembelajaran dan para pengajar merencanakan aktivitas belajar mengajar. Model pembelajaran mengarahkan guru dalam mendesain proses pembelajaran untuk membantu siswa agar tujuan pembelajaran tercapai. Melihat permasalahan yang ada, model pembelajaran yang cocok atau tepat untuk mengatasi permasalahan tersebut adalah model pembelajaran berbasis masalah atau Problem Based Learning (PBL).

Model pembelajaran problem based learning (PBL) merupakan model pembelajaran yang menerapkan permasalahan nyata atau permasalahan sehari-hari sebagai konteks untuk melatih para siswa dalam mengembangkan sikap berpikir kritis, kemampuan memecahkan masalah dan memperoleh pengetahuan (Duch dalam Shoimin, 2014). Model pembelajaran ini mendorong siswa untuk mengasah dan menguji kemampuan untuk berpikir dalam memecahkan sesuatu masalah. Ward (dalam Ngalimun, 2012) mengatakan bahwa Problem Based Learning (PBL) adalah suatu model yang melibatkan siswa untuk memecahkan masalah melalui tahap-tahap atau metode ilmiah, sehingga membuat siswa dapat belajar atau mencari tahu pengetahuan yang berhubungan dengan masalah tersebut sekaligus memiliki keterampilan untuk memecahkan masalah. Dalam model pembelajaran problem based learning, kemampuan siswa dapat dioptimalkan salah satunya dengan pengamatan secara langsung dan kerja kelompok sehingga mengembangkan kemampuan berpikir kritis untuk memecahkan masalah dan mendorong siswa lebih aktif dan membuka kesempatan untuk menumbuhkan rasa ingin tahu siswa secara alamiah untuk membantu mengembangkan kemampuan bertanya dan mencari jawaban berdasarkan bukti yang ada untuk meningkatkan sikap berpikir kritis dan hasil belajarnya.

Berdasarkan hasil penelitian sebelumnya yang dilakukan oleh Muslihudin (2019) diperoleh hasil bahwa model Problem Based Learning dapat meningkatkan kemampuan berpikir kritis siswa kelas IV SD N 1 Suganangan pada muatan pelajaran IPS karena dalam proses pembelajaran siswa dilatih untuk mengatasi permasalahan secara mandiri sehingga siswa mampu untuk memecahkan permasalahan dunia nyata sesuai dengan tahap-tahap model Problem Based Learning. Hal ini dibuktikan dengan perolehan skor nilai kemampuan berpikir kritis pada siklus I dengan rata-rata 74 dengan kriteria baik dan meningkat pada siklus II diperoleh niali rata-rata 82 dengan kriteria sangat baik. Penelitian lainnya yang dilakukan oleh Oktaferi dan Desyandri (2020) juga menunjukkan hasil bahwa model Problem Based Learning dapat meningkatkan kemampuan berpikir kritis siswa kelas IV SD N 16 Campago Ipuh, dengan persentase nilai yang diperoleh pada siklus 1 pertemuan 1 sebesar 47,53\%, siklus 1 pertemuan 2 sebesar 70,26\%, dan siklus 2 meningkat menjadi 88,52\%. Dari dua penelitian tersebut variabel penelitian hanya fokus pada kemampuan berpikir kritis siswa pada muatan pelajaran tertentu. Sedangkan pada penelitian ini, berdasarkan permasalahan yang telah diuraikan sebelumnya, penelitian dilakukan untuk meningkatkan kemampuan berpikir kritis dan hasil belajar Siswa Kelas V untuk muatan pelajaran IPA.

\section{Metode Penelitian}

Jenis penelitian yang digunakan adalah penelitian tindakan kelas (PTK). Menurut Tampubolon (2014), Penelitian Tindakan Kelas (PTK) adalah penelitian yang dilakukan oleh pendidik/calon pendidik di dalam kelasnya sendiri secara kolaboratif/partisipatif untuk memperbaiki kinerja pendidik menyangkut kualitas proses pembelajaran, dan meningkatkan 
hasil belajar peserta didik, baik dari aspek akademik maupun non-akademik, melalui tindakan reflektif dalam bentuk siklus. Tujuan dari penelitian ini adalah untuk meningkatkan kemampuan berpikir kritis dan hasil belajar IPA siswa yang masih rendah. Model yang digunakan adalah model Kemmis \& Mc Taggart (dalam Arikunto, 2016) yang didesain dalam bentuk dua siklus yang terdiri dari tahap perencanaan tindakan (planning), pelaksanaan tindakan (acting), pengamatan (observing) dan refleksi (reflecting).

Penelitian ini dilaksanakan di SD Kanisius Sengkan dengan subjek penelitian yaitu siswa kelas V SD Kanisius Sengkan yang berjumlah 29 siswa. Teknik pengumpulan data yang digunakan yaitu tes (berupa tes tertulis/evaluasi untuk mengumpulkan data terkait kemampuan berpikir kritis dan hasil belajar siswa) dan non tes (berupa observasi dan wawancara untuk mengumpulkan data terkait permasalahan yang terjadi di sekolah dan juga data terkait kemampuan berpikir kritis siswa saat proses pembelajaran di kelas). Instrumen penelitian yang digunakan berupa instrumen observasi, instrumen wawancara, dan instrumen tes. Analisis data dalam penelitian ini menggunakan analisis data kuantitatif dan analisis data kualitatif. Analisis data kuantitatif digunakan untuk mendeskripsikan kemampuan berpikir kritis dan hasil belajar siswa yang diukur dari soal evaluasi siklus I dan siklus II. Analisis data kualitatif digunakan untuk mendeskripsikan permasalahan yang terjadi di kelas dan kemampuan berpikir kritis siswa saat mengikuti proses pembelajaran yang dilihat dari hasil observasi dan wawancara.

\section{Hasil dan Pembahasan}

Hasil penelitian menunjukkan bahwa terjadi peningkatan pada kemampuan berpikir kritis dan hasil belajar siswa melalui penerapan model pembelajaran Problem Based Learning (PBL) di kelas V SDK Sengkan. Peningkatan kemampuan berpikir kritis dan hasil belajar tidak lepas dari peran penting 5 langkah pembelajaran problem based learning. Kelima langkah tersebut adalah memberikan orientasi permasalahan kepada siswa, mengorganisasikan siswa untuk belajar, membantu investigasi mandiri dan kelompok, mengembangkan dan mempresentasikan hasil karya, menganalisis dan mengevaluasi.

1) Memberikan Orientasi Permasalahan Kepada Siswa

Pada langkah ini guru fokus untuk memberikan siswa sebuah permasalahan untuk dianalisis. Permasalahan bisa diberikan secara individu maupun kelompok. Tujuannya yaitu supaya siswa dapat memecahkan sebuah masalah dan kritis terhadap sesuatu yang terjadi. Dengan begitu, siswa tidak hanya menerima penjelasan dari guru saja akan tetapi memiliki pemikiran sendiri terhadap materi yang disampaikan. Permasalahan yang akan diberikan kepada siswa dapat dilakukan dengan berbagai cara sesuai dengan kreativitas guru. Permasalahan yang diberikan merupakan cara untuk melatih kemampuan berpikir kritis siswa. Pada langkah ini guru juga dapat memotivasi siswa untuk terlibat aktif dalam pembelajaran dan mendefinisikan permasalahan. Kemampuan berpikir kritis siswa sangat dibutuhkan dalam meyelesaikan suatu masalah. Siswa yang mengalami proses berpikir kritis akan dengan mudah menyelesaikan suatu masalah. Hal itu sejalan dengan Halpern (dalam Sani, 2019) mengatakan proses berpikir kritis diperlukan dalam meyelesaikan suatu permasalahan. Permasalahan yang diberikan juga harus berkaitan dengan kehidupan nyata siswa. 
2) Mengorganisasikan Siswa Untuk Belajar

Dalam langkah ini peneliti sebagai guru bertugas untuk memastikan setiap siswa untuk mengikuti pembelajaran. Cara peneliti mengorganisasikan siswa untuk belajar yaitu dengan membagi siswa ke dalam beberapa kelompok. Setiap kelompok tersebut terdiri dari 5-6 anggota. Tujuan belajar kelompok yaitu agar siswa lebih mudah memahami masalah yang diberikan dan membagikan pemikirannya dalam kelompok. Langkah ini awali dengan siswa berdiskusi di dalam kelompok untuk menemukan informasi atau cara-cara menangani masalah yang telah diberikan. Setiap siswa wajib menuangkan pemikirannya terhadap masalah yang kemudian dituliskan dalam LKPD kelompok. Peneliti meyakini bahwa dengan berdiskusi kelompok siswa akan lebih mudah memahami masalah. Siswa dapat mengingat informasi yang didapatkan dari diskusi. Hal itu sejalan dengan pendapat Melani (dalam Aprilianti, dkk, 2018) mengatakan bahwa dengan diskusi kelompok siswa akan lebih mengingat apa yang didiskusikan daripada menerima penjelasan guru. Aprilianti, dkk (2018) menambahkan bahwa diskusi juga dapat meningkatkan pemahaman, pengetahuan dan ketajaman berpikir siswa.

3) Membantu Investigasi Mandiri dan Kelompok

Pada langkah ini peneliti lebih mengamati siswa dalam mengungkapkan pendapat atau ide dalam kelompok. Investigasi yang dimaksud yaitu siswa dalam masing-masing kelompok mengindentifikasi solusi dari permasalahan dan menuangkan pendapat atau ide yang ada dalam pikiran siswa untuk menyelesaikan permasalahan yang ada. Investigasi mandiri yaitu setiap masing-masing siswa dalam kelompok wajib memikirkan satu solusi untuk menyelesaikan masalah yang diberikan. Kegiatan ini memberikan siswa kesempatan untuk mengembangkan keterampilan penyelidikan dengan begitu kemampuan berpikir kritis siswa akan muncul dan berkembang. Siswa menjadi lebih paham dengan materi yang diajarkan dan mengingatnya dengan lama. Hal itu dapat meningkatkan hasil belajar siswa ketika mengerjakan soal evaluasi. Hal ini sejalan dengan pendapat Widodo (2013) yang mengungkapkan bahwa problem based learning dikembangkan untuk membantu siswa mengembangkan kemampuan berpikir, mengatasi masalah, keterampilan penyelidikan, kemampuan mempelajari peran sebagai orang dewasa melalui keterlibatan mereka dalam pengalaman nyata atau simulasi, dan menjadi pembelajar yang mandiri dan independen.

4) Mengembangkan Dan Mempresentasikan Hasil Karya

Dalam penelitian ini, setiap kelompok diminta untuk menyiapkan laporan berupa poster dari hasil diskusi kelompok secara rapi. Poster yang dibuat berkaitan dengan cara merawat organ pernapasan. Poster yang telah dibuat kemudian selanjutnya dipresentasikan di depan kelas. Setiap kelompok melakukan presentasi sesuai dengan nomor urutan. Masing-masing siswa wajib memaparkan atau terlibat atas karya kelompok pada saat presentasi. Keterlibatan setiap siswa dalam presentasi sangat penting untuk menunjukkan seberapa paham siswa terhadap masalah yang hadapi. Dalam problem based learning siswa harus terlibat secara utuh untuk memecahkan masalah. Hal itu sejalan dengan Nuraini (2017) yang mengatakan bahwa problem based learning adalah model pembelajaran yang mengakomodasi keterlibatan siswa dalam belajar dan pemecahan masalah. Siswa harus ikut serta dalam aktivitas belajar dengan mengeluarkan pendapat atau berbagai pemikiran. 
5) Menganalisis dan Evaluasi

Pada langkah ini peneliti membantu siswa untuk menganalisis dan mengevaluasi dari pemecahan masalah dan hasil penyelidikan yang telah dilakukan. Pada langkah ini kelompok mencoba untuk menjelaskan pengetahuan yang diperoleh dari diskusi. Setiap kelompok memiliki topik-topik pembahasan yang berbeda sesuai dengan masalah yang didapatkan. Penjelasan kelompok diutarakan melalui presentasi yang dilakukan pada langkah mengembangkan dan mempresentasikan hasil karya. Setiap kelompok memiliki gagasan yang berbeda sesuai dengan apa yang ada dalam pikirannya. Evaluasi dilakukan dengan meminta siswa mengutarakan gagasan atau tanggapannya terhadap hasil karya yang dipresentasikan oleh kelompok yang lain. Selain itu kelompok yang tidak presentasi dapat bertanya kepada kelompok yang presentasi. Kelompok yang tidak presentasi dapat memberikan tanggapan ataupun juga masukan terhadap hasil karya dari kelompok yang melakukan presentasi agar hasil pembelajaran akan semakin baik. Selain itu, setiap kelompok yang mendengarkan presentasi dari kelompok lain juga dapat memberikan informasi-informasi yang berkaitan dengan topik yang dipresentasikan jika informasi yang diutarakan dianggap kurang lengkap. Informasi yang disampaikan tentunya sesuai dengan fakta yang telah siswa ketahui. Siswa dalam mengutarakan informasi tentang masalah yang ada pastinya sudah melakukan investigasi masalah untuk menemukan solusinya. Hal itu sejalan dengan Rahyubi (dalam Nuraini, 2017) yang mengungkapkan bahwa dalam pemerolehan informasi dan pengembangan pemahaman tentang topik-topik, siswa belajar bagaimana mengkonstruksi kerangka masalah, mengorganisasikan dan menginvestigasi masalah, mengumpulkan dan menganalisis data, menyusun fakta, mengkonstruksi argumen mengenai pemecahan masalah, bekerja secara individual atau berkolaborasi dalam pemecahan masalah.

\section{Peningkatan Kemampuan Berpikir Kritis dan Hasil Belajar Siswa}

Hasil analisis data pada variabel kemampuan berpikir kritis siswa menunjukkan nilai rata-rata kemampuan berpikir kritis pada siklus I mencapai 64,18 dan meningkat pada siklus II dengan nilai rata-rata yaitu 80,38 . Adapun hasil peningkatan kemampuan berpikir kritis siswa dapat dilihat dari grafik berikut ini.

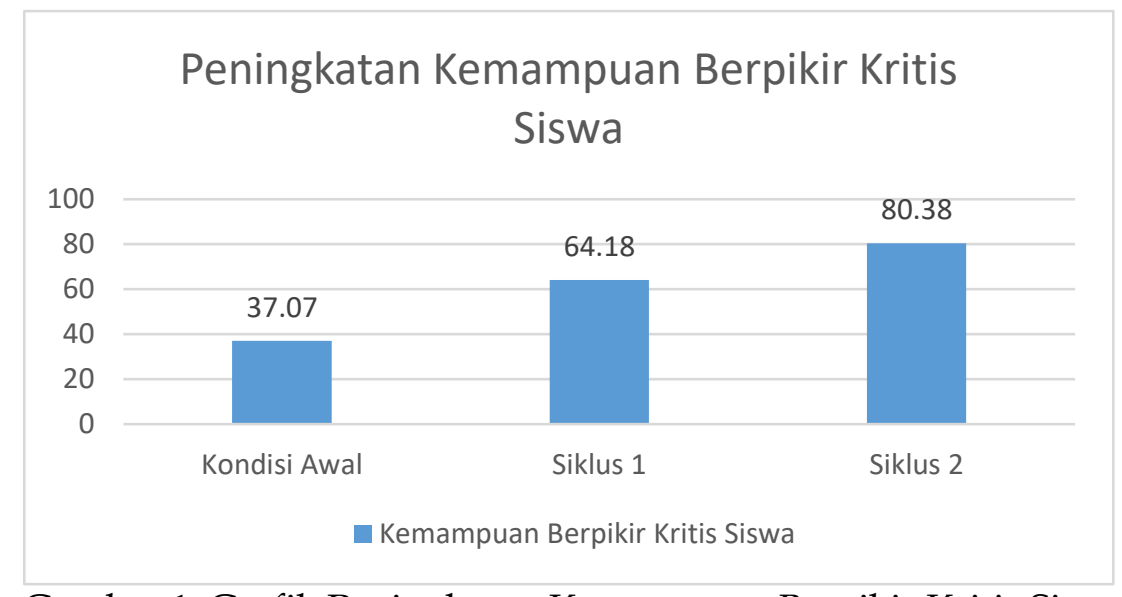

Gambar 1. Grafik Peningkatan Kemampuan Berpikir Kritis Siswa

Peningkatan pada kemampuan berpikir kritis ini tidak lepas dari penggunaan model pembelajaran problem based learning. Penerapan model pembelajaran problem based learning 
dapat membangun rasa semangat belajar melalui suatu permasalahan nyata yang diorientasikan pada siswa. Pada penelitian ini, orientasi masalah diberikan melalui tayangan video terkait topik yang dipelajari. Permasalahan dalam video tersebut dapat merangsang rasa penasaran yang ada dalam pikiran siswa dan menstimulus kemampuan berpikir kritis siswa serta memunculkan beragam pertanyaan atau ide yang ada di benaknya untuk menyelesaikan masalah yang ada. Masalah yang dimunculkan dalam pembelajaran bersifat kontekstual dan berkaitan dengan kehidupan nyata, sehingga siswa akan lebih kritis dan tanggap akan pembelajaran jika berkaitan langsung dengan apa yang dialaminya. Pertanyaan-pertanyaan pun akan terus bermunculan di benaknya karena sudah memiliki informasi dari pengalamannya, sehingga dapat menstimulus kemampuan berpikir kritisnya. Penjelasan tersebut diperkuat oleh Nurhadi (dalam Wedyawati \& Lisa, 2019) yang mengatakan bahwa problem based learning adalah suatu model pembelajaran yang menggunakan masalah dunia nyata sebagai suatu konteks bagi siswa untuk belajar tentang cara berpikir kritis dan keterampilan pemecahan masalah, serta memperoleh pengetahuan dan konsep yang esensial dari materi pelajaran. Selain itu, dalam pembelajaran problem based learning siswa dituntut untuk terlibat dan kritis terhadap pembelajaran. Keterlibatan tersebut dapat dilihat pada kegiatan mengumpulkan informasi atau diskusi dalam pemecahan masalah yang dilakukan oleh siswa. Siswa mengutarakan apa yang ada di pikirannya terkait solusi dari permasalahan yang sedang didiskusikan. Melalui kegiatan diskusi tersebut, siswa dapat mengutarakan pertanyaan atau pendapat yang berbeda sesuai dengan pemahaman yang dimilikinya. Kegiatan diskusi dapat memicu rasa antusias siswa terhadap solusi yang ditemukan oleh siswa lainnya, sehingga memunculkan pertanyaan-pertanyaan yang dapat merangsang kemampuan berpikir kritisnya. Sejalan dengan Pierce dan Jones (dalam Wulandari, 2013) yang mengatakan bahwa kejadian yang harus muncul dalam implementasi problem based learning (PBL) adalah keterlibatan. Pendapat tersebut diperkuat oleh Glazer (dalam Nafiah, 2014) menyatakan bahwa PBL menekankan belajar sebagai proses yang melibatkan pemecahan masalah dan berpikir kritis dalam konteks yang sebenarnya.

Hasil analisis data pada variabel hasil belajar siswa menunjukkan persentase ketuntasan hasil belajar siswa pada siklus I mengalami peningkatan mencapai 79,31\% dengan nilai ratarata yaitu 76,21, dan terus mengalami peningkatan pada siklus II dimana persentase ketuntasan hasil belajar siswa mencapai $93,10 \%$ dengan nilai rata-rata yang diperoleh sebesar 82,19 . Peningkatan hasil belajar siswa dapat dilihat pada grafik berikut ini.

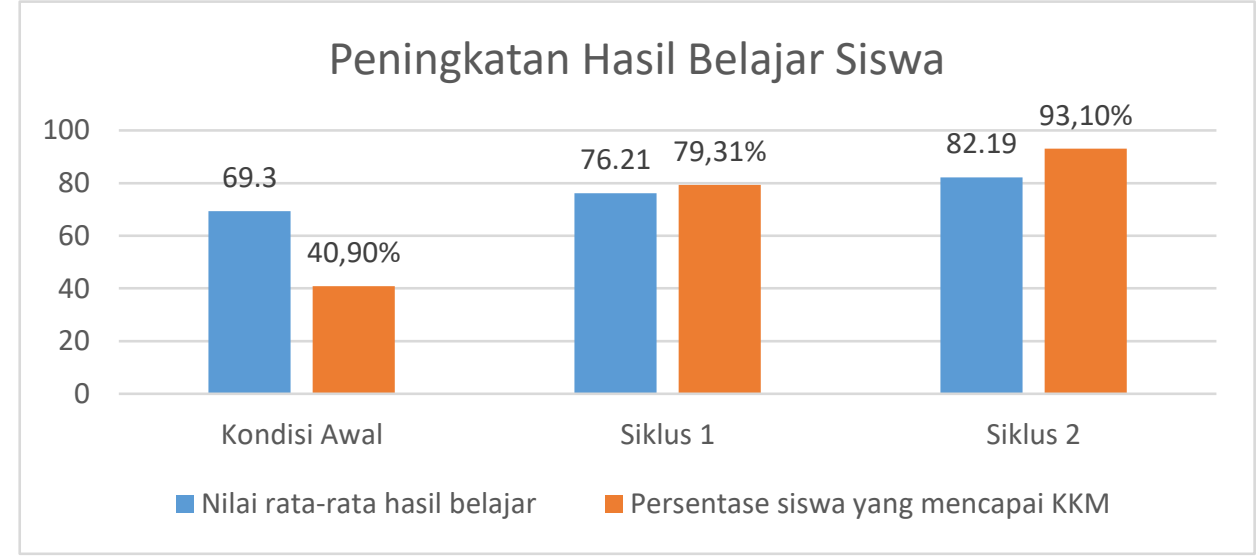

Gambar 2. Grafik Peningkatan Hasil Belajar Siswa 
Penerapan pembelajaran berbasis masalah yang berkaitan dengan kehidupan sehari-hari membuat siswa lebih mudah memahami materi dipelajari dan lebih mudah diingat dalam jangka panjang. Siswa mengalami langsung pembelajaran, sehingga pembelajaran dengan mudah tertanam dalam pikirannya. Hal itu juga membuat siswa merasakan bahwa pembelajaran yang berlangsung sangat bermakna dan terekam dengan jelas di dalam memorinya. Hal ini diperkuat oleh pendapat Kunandar (dalam Lismaya, 2019) yang mengatakan bahwa problem based learning adalah suatu model pembelajaran yang menggunakan masalah dunia nyata sebagai suatu konteks bagi siswa untuk belajar tentang cara berpikir dan keterampilan menyelesaikan masalah serta untuk memperoleh pengetahuan dan konsep yang esensial dari mata pelajaran. Sejalan dengan pendapat tersebut, Muniroh (2015) juga mengungkapkan bahwa penerapan PBL dirancang untuk membantu siswa mengembangkan keterampilan kognitif dan menyelesaikan masalah melalui berbagai situasi riil atau disimulasikan dalam kelas. Hal itu membuat siswa mengingat dengan jelas materi yang diajarkan sehingga memudahkan siswa mengerjakan soal evaluasi yang diberikan. Selain itu, dalam model pembelajaran problem based learning siswa diajak untuk menyelesaikan masalah melalui diskusi kelompok. Kegiatan berdiskusi kelompok memudahkan siswa dalam menyerap informasi yang diterima, sehingga siswa dapat mencapai ketuntasan dalam proses pembelajarannya. Hal ini sesuai dengan pendapat Al-Tabany (2017) yang mengatakan bahwa salah satu keunggulan dari problem base leaning adalah pengondisian siswa dalam belajar kelompok yang saling berinteraksi terhadap pembelajar dan temannya, sehingga pencapaian ketuntasan belajar dapat diharapkan. Proses pemecahan masalah dalam problem based learning juga memiliki peran penting untuk memuculkan kesadaran diri dalam menumbuhkan tanggung jawab, keingintahuan akan belajar dan komitmen pribadi untuk mencapai tujuan. Hal itu sesuai dengan pendapat Muniroh (2015) yang mengatakan bahwa proses pemecahan masalah memainkan peran penting untuk memaksimalkan terbangunnya kesadaran diri sebagai landasan untuk menumbuhkan tanggung jawab dalam belajar yang pada gilirannya meningkatkan komitmen pribadi untuk mengerahkan usaha mencapai tujuan. Tujuan yang ingin dicapai yang dimaksud yaitu memperoleh nilai yang baik dalam proses pembelajaran sehingga dapat meningkatkan hasil belajar.

Berdasarkan hasil penelitian yang telah diuraikan tersebut diketahui bahwa tujuan penelitian ini telah tercapai yang ditunjukkan dengan pencapaian indikator keberhasilan yaitu kemampuan berpikir kritis dan hasil belajar IPA siswa yang mengalami peningkatan dengan penerapan model problem based learning.

\section{Kesimpulan}

Berdasarkan uraian-uraian yang telah dipaparkan di atas, dapat disimpulkan bahwa penerapan model Problem Based Learning (PBL) dapat meningkatkan kemampuan berpikir kritis dan hasil belajar siswa. Hal ini ditunjukkan dari hasil analisis data pada variabel kemampuan berpikir kritis siswa menunjukkan peningkatan nilai rata-rata kemampuan berpikir kritis mencapai 64,18 pada siklus I dan 80,38 pada siklus II. Sedangkan hasil analisis data pada variabel hasil belajar siswa menunjukkan peningkatan persentase ketuntasan hasil belajar siswa mencapai 79,31\% dengan nilai rata-rata yaitu 76,21 pada siklus I dan mencapai 93,10\% dengan nilai rata-rata yang diperoleh sebesar 82,19 pada siklus II. Berdasarkan hasil penelitian ini diharapkan ke depannya semakin banyak implementasi model-model 
pembelajaran inovatif yang diterapkan guru dalam proses pembelajaran di SD salah satunya dengan model Problem Based Learning agar pengalaman pembelajaran yang diberikan bagi siswa bisa semakin bermakna dan berkualitas.

\section{Daftar Pustaka}

Al-Tabany, T.I. (2017). Mendesain model pembelajaran inovatif, progresif, dan kontekstual. Jakarta: Kencana.

Aprilianti, L. Irawati, S \& Kasrina. (2018). Peningkatan Sikap Ilmiah $\quad$ dan Hasil Belajar Siswa dengan Model Problem Based Learning. Jurnal Pendidikan dan Pembelajaran Biologi. 2(1):58-67.

Arikunto, S. (2016). Prosedur penelitian suatu pendekatan praktik. Jakarta: Rineka Cipta.

Facione P. A. (2013). Critical Thinking: What it is and why it counts. Measured Reasons and the California Academic Press, Millbrae, CA.

Fisher, A. (2009). Berpikir Kritis Sebuah Pengantar. Terj. Benyamin Hadinata, Jakarta: Erlangga.

Lismaya, L. (2019). Berpikir Kritis \& PBL (Problem Based Learning). Surabaya: Media Sahabat Cendekia.

Muniroh, A. (2015). Penerapan Model Problem Based Learnig di Madrasah. Yogyakarta: LKS Pelangi Aksara.

Muslihudin, A. (2019). Penerapan Model Problem Based Learning Dalam Meningkatkan Kemampuan Berpikir Kritis Siswa Sekolah Dasar. Jurnal Elementaria Edukasia. 2(2): 194205.

Nafiah, Y. N \& Suyanto, W. (2014). Penerapan Model Problem Based Learning untuk Meningkatkan Keterampilan Berpikir Kritis dan Hasil Belajar Siswa. Jurnal Pendidikan Vokasi. 4(1): 125-143.

Ngalimun. (2012). Strategi dan model pembelajaran. Yogyakarta: Aswaja Pressindo.

Nuraini, F. (2017). Penggunaan Model Problem Based Learning (PBL) untuk Meningkatkan Hasil Belajar IPA Siswa Kelas 5 SD. E-Jurnal Mitra Pendidikan. 1(4) : 369-378.

Oktaferi, R., \& Desyandari (2020). Peningkatan Kemampuan Berpikir Kritis Menggunakan Model Problem Based Learning (PBL) pada Tematik Terpadu di Sekolah Dasar. Jurnal Pendidikan Tambusai. 4(3):2637-2646.

Prihanti, G. S. (2015). Strategi belajar. Malang: Universitas Muhammadiyah Malang.

Purwanto. (2013). Evaluasi Hasil Belajar. Yogyakarta: Pustaka Pelajar.

Riyana, C. (2012). Media pembelajaran. Jakarta Pusat: Kementrian Agama RI.

Rusman. (2012). Model-model Pembelajaran. Depok: PT. Rajagrafindo Persada.

Sani, R. A. (2019). Pembelajaran berbasis HOTS (higher order thingking skills). Tangerang: Tira Smart.

Shoimin, A. (2014). 68 model pembelajaran inovatif dalam kurikulum 2013. Yogyakarta: Ar-Ruzz Media.

Suprijono, A. (2016). Model-model pembelajaran emansipatoris. Yogyakarta: Pustaka Pelajar.

Tampubolon, S. M. (2014). Penelitian Tindakan Kelas. Jakarta: PT. Gelora Aksara Pratama.

Wedyawati, N \& Lisa, Y. (2019). Pembelajaran IPA di sekolah dasar. Yogyakarta: CV Budi Utama. 
Widodo, L. W. (2013). Peningkatan Aktivitas Belajar dan Hasil Belajar Siswa dengan Model Problem Based Learning pada Siswa Kelas VIIA MTs Negeri Donomulyo Progo. Jurnal Fisika Indonesia. 17(49) : 32-35.

Wulandari, B \& Surjono, H.D. (2013). Pengaruh problem based learning terhadap hasil belajar ditinjau dari motivasi belajar PLC di SMK. Jurnal Pendidikan Vokasi. 3(2): 178-19. 